\title{
THE LAST MOUNTAIN LAKE WILDLIFE AREA, SASKATCHEWAN
}

by J. P. Hatfield, Canadian Wildlife Service, Simpson, Saskatchewan
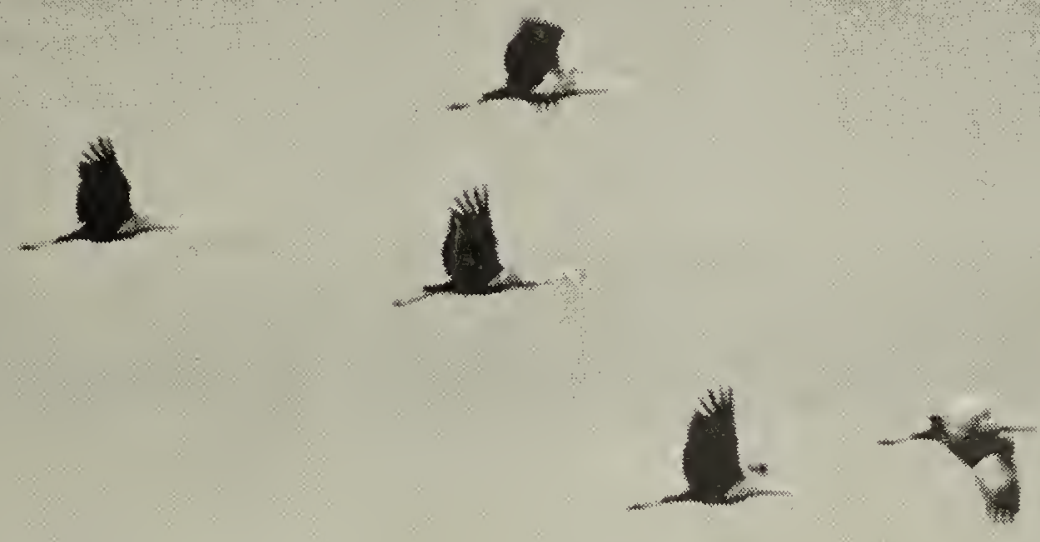

Sandhill Cranes at Last Mountain Lake, October, 1963

Last Mountain is a "blue bump" on the open prairie about 50 miles north of Regina, Saskatchewan. It was a landmark in the early days of furtrading and buffalo hunting in that territory. Ten miles west of Last Mountain is a lake, named after the "mountain" and also known locally as Long Lake, since it is 55 miles in length and seldom exceeds two miles in width. The north end of this lake is approximately 80 miles north of Regina and 100 miles southeast of Saskatoon, Saskatchewan.

On June 8, 1887, the islands and parts of the adjoining shore of the northern 11 miles of Last Mountain Lake were "reserved from sale and settlement and set apart as breeding grounds for wild fowl." This was the first area reserved for wildlife in North America by a Federal Government. After the Migratory Birds Convention Act was passed in 1917, the reserve became known as the Last Mountain Lake Bird Sanctuary.

In April 1966 a statement of $\mathrm{Na}$ tional Wildlife Policy and Program was made in the House of Commons. The policies allowed purchase and management of land to preserve and improve migratory bird habitat and to influence local distribution of birds as a means of controlling damage to cereal crops.

Crop depredation by Sandhill Cranes (Grus canadensis) and waterfowl of commercial cereal crops at the north end of Last Mountain Lake has been an acute problem over the past 20 years. The rising costs of farming aggravated this situation. In an effort to alleviate this problem the Canadian Wildlife Service purchased 14,620 acres of marginal farm lands around the north end of Last Mountain Lake, thus establishing the first Federal Widlife Area in Canada. Approximately 8,500 acres of Crown land administered by the Province of Saskatchewan are located adjacent to this Wildlife Area. Management of the combined area is coordinated by the Canadian Wildlife Service. In cooperation with the Wildlife Branch of the Saskatchewan Department of Natural Resources a wildlife management area is being established and is called the Last Mountain Lake Wildlife Area. 


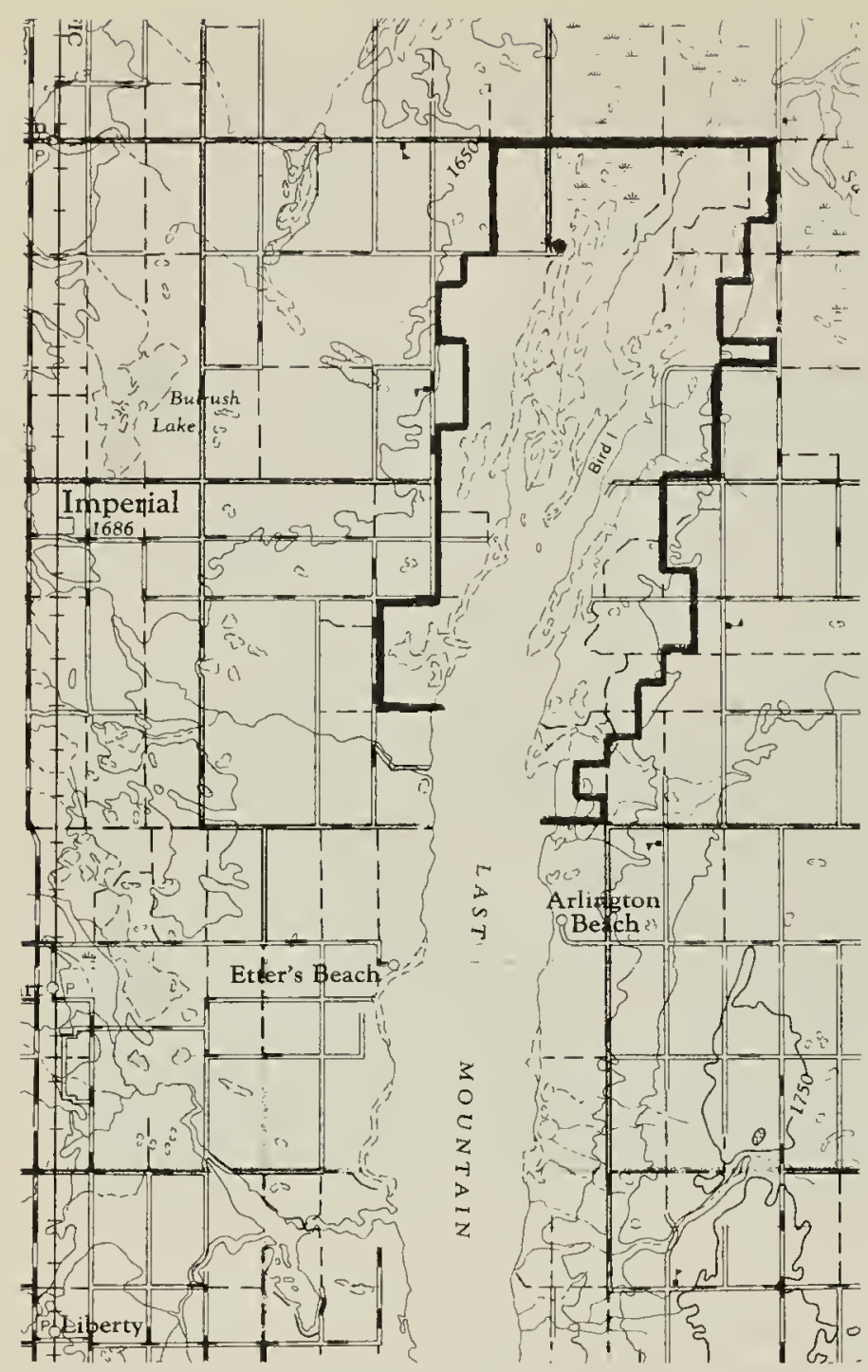

Boundaries of Last Mountain Lake Wildlife Area, 1969.

The Wildlife Area can be reached from the 'Trans-Canada Highway by driving to Govan or Hatfield some 80 miles north of Regina, on Highways 11 and 20. The lake is about nine miles west of those towns and can be reached by side roads. An alternative route, should you be driving from the west on the Trans-Canada Highway, is via Highway 2, north from Moose Jaw to Imperial or Simpson. The lake is approximately eight miles east of those towns. Simpson is 90 miles southeast of Saskatoon on Highways 14 and 2 respectively. The main country roads around the Wildlife Area are gravelled, but the side roads tend to get very muddy during rain showers.

The Wildlife Area lies in typical transition zone between grassland and forest. Topography is gently to moderately undulating. Soil texture is light with extensive alkaline areas.
Animals characteristic of the transition zone are common, but the most notable feature of native fauna is the variety and abundance of both migra. tory and resident birds. In 1968 over one hundred species of birds were observed. The number of bird species could top the two hundred mark as the area becomes better known. At least five Sharp-tailed Grouse (Pedioecetes phasianellus) dancing grounds exist. The author has observed eight Whooping Cranes (Grus americana) either on or near the area over the past two years. During the fall migration period up to 20,000 Sandhill Cranes, 10,000 Double-crested Cormorants (Phalacrocorax auritus), 4,000 Whistling Swans (Olor columbianus), thousands of ducks and large numbers of other birds may be seen at the north end of Last Mountain Lake. A large variety of wild flowers can be seen from May to October throughout the area.

With the formation of the Wildlife Area from an existing federal bird sanctuary, provincial game preserve and acquired agricultural land, changes in land use have occurred. By June of this year 7,155 acres of former grain producing land have been con-

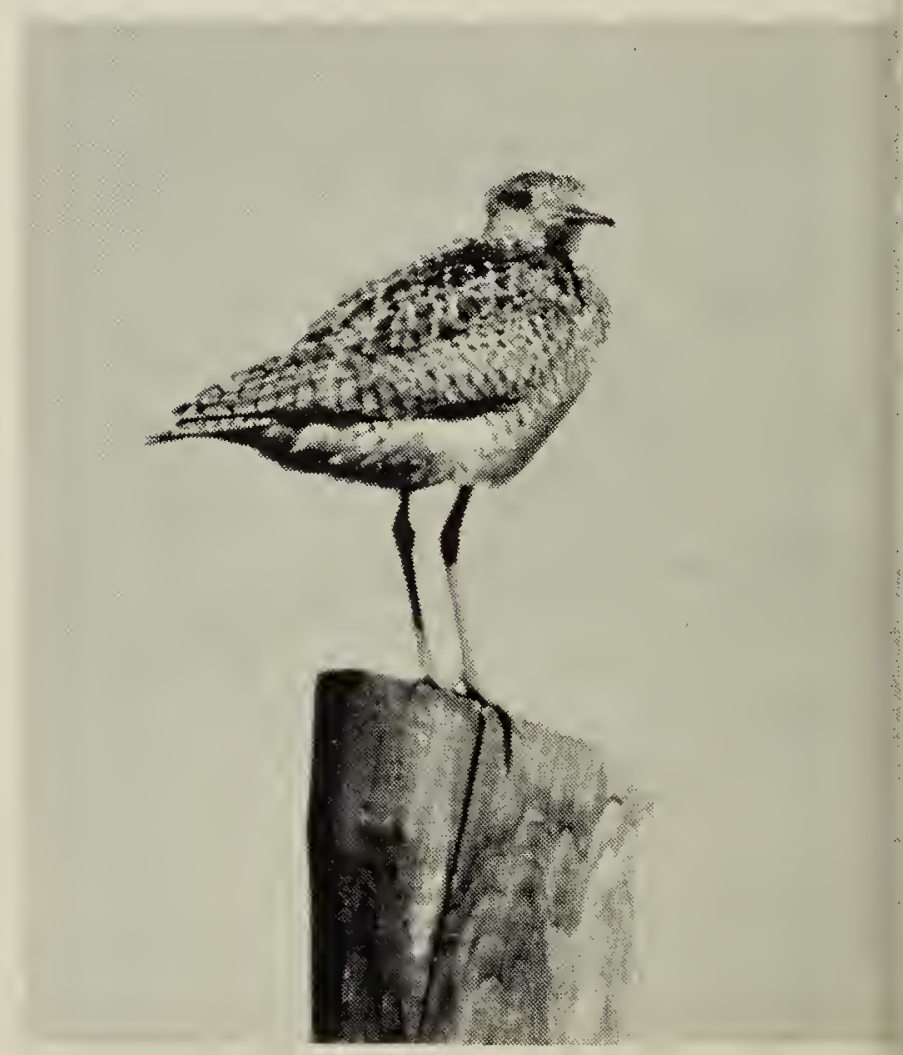

Upland Plover near Last Mountain Lake, 1966 

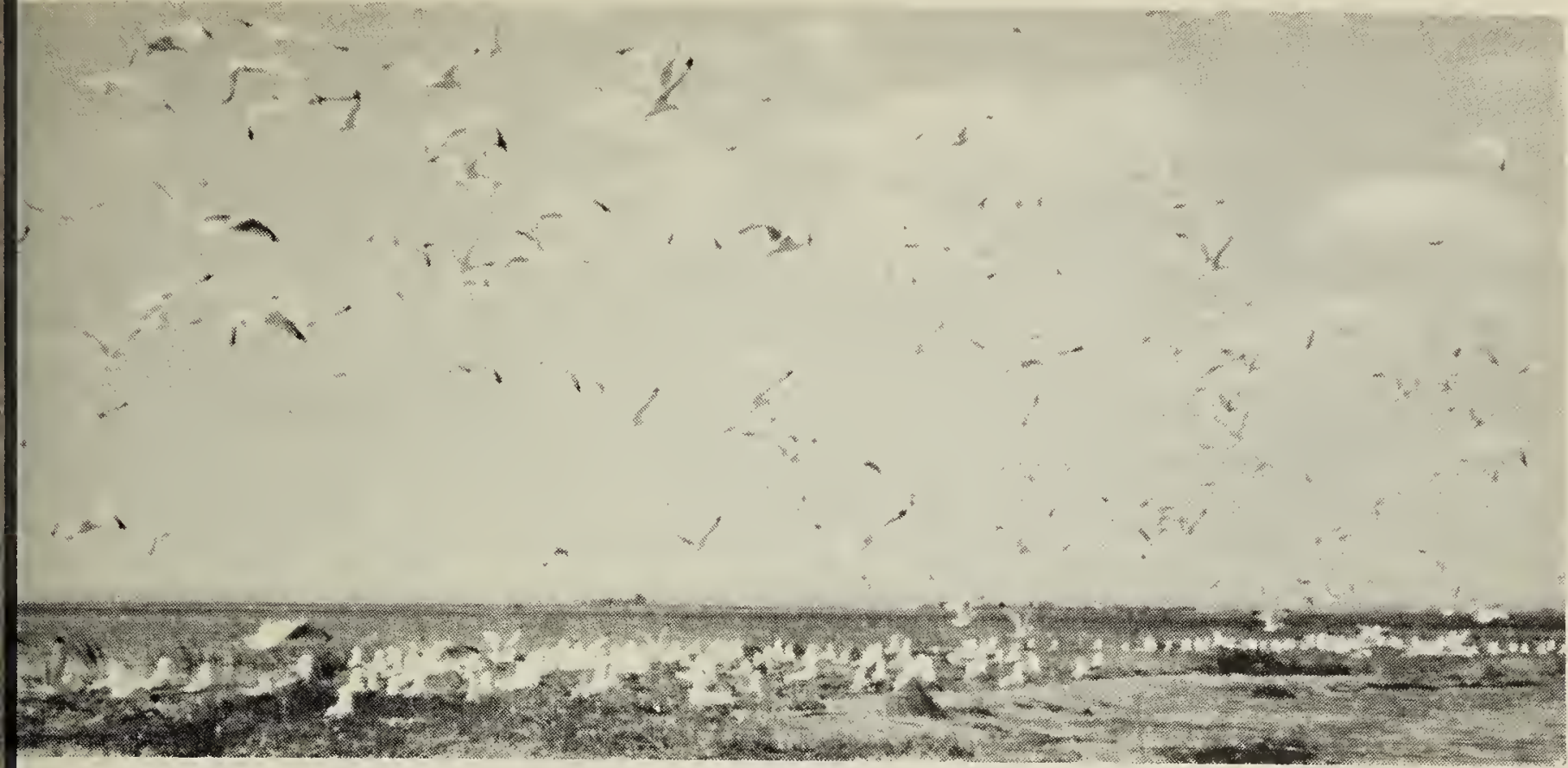

Ring-billed Gull colony at Last Mountain Lake, May, 1969

erted to forage production. The orage will provide nesting cover for irds and act as buffer zones between ure crops and commercial cereal rops grown outside of the area. Local armers will be allowed to cut and emove the forage after the nesting eriod is over. The haying operations fill promote green forage for grazing eese and will reduce the fire hazard $y$ the removal of excess grass.

Barley is sown in lure crops to lleviate depredation on surrounding ommercial cereal crops by Sandhill ranes and waterfowl. Lure crops are lanted on 17 plots of 60 acres each, rategically located around the Wildfe Area. Grazing is allowed on a mited basis on seven small pastures. h some pastures grazing helps to introl emergent marsh vegetation. this were not done the marsh vegeation would get so thick that young ucks could not move freely in their arch for food.

Public activities on the Wildlife rea include fishing, swimming, camp$\mathrm{g}$, boating, nature study, picnicking, unting and hiking. Guided tours can e arranged for groups by contacting he Project Manager.

Future plans call for the construcon of a nature interpretative centre ear the headquarters of the Wildlife
Area. Here the public will be informed of the natural features and management operations, and where they can be seen. Other development plans include the planting of shelter belts for wildlife cover, the construction of ponds for waterfowl and the marking of nature trails.

A visit to the Last Mountain Lake Wildlife Area, especially during the months of May, June, September or October, could be an experience of a lifetime.

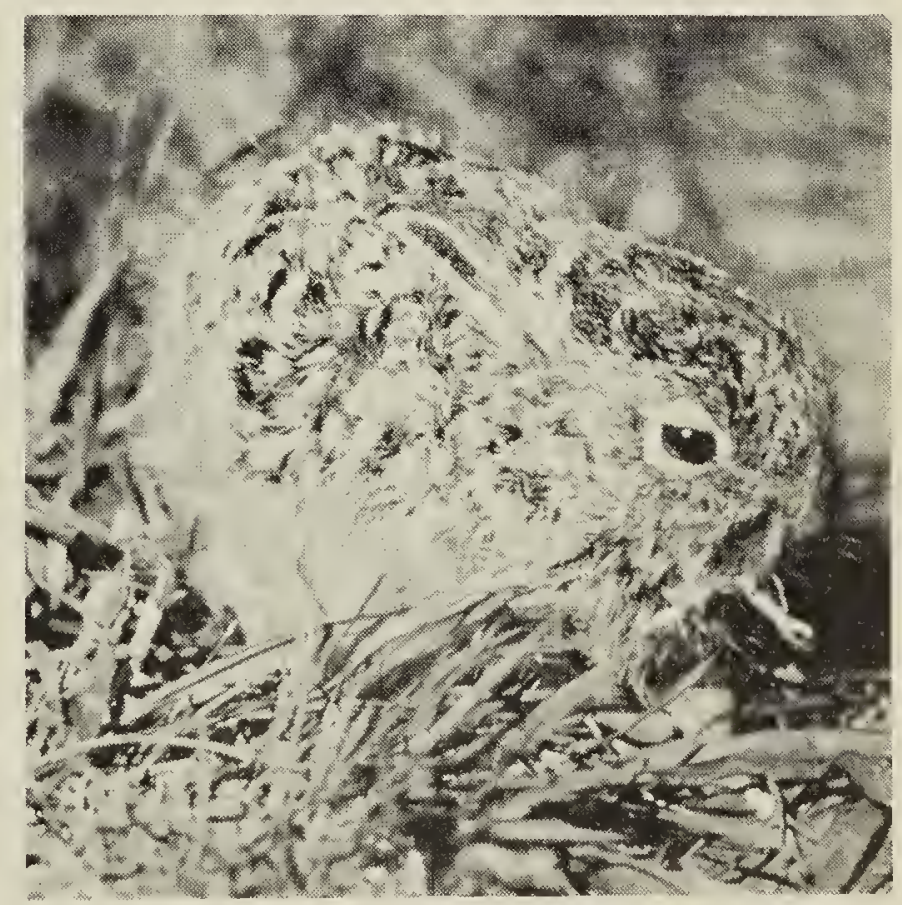

Photos by J. P. Hatfield

Young White-tailed Jack Rabbit in the sanctuary, May, 1969. 